УДК 655.326.1: 621.798

\title{
SIMULATION OF STRESS-STRAIN STATE OF CORRUGATED CARDBOARD IN FLEXOGRAPHIC PRINTING AND ITS INFLUENCE ON IMPRINTS QUALITY
}

\author{
M. Ohirko, S. Havenko, M. Labetska, J. Czubak \\ Ukrainian Academy of Printing, \\ 19, Pid Holoskom St., Lviv, 79020, Ukraine
}

The simulation of the stress-strain state of five-layer corrugated cardboard during printing on a sheet flexographic machine is carried out. The research is based on the basic equations of the calculation theory of stresses and strains, which take into account geometric and physical nonlinearity in elastic bodies made of incompressible material, which is under the action offorce fields. To determine the optimal stress-strain state of corrugated cardboard, a difference method of increasing accuracy is adopted. The maximum deformations during compression of the corrugated sheet structure printed on the side of the corrugation $B$ and E, depending on the applied force for different values of the angle at the base of the corrugation wave are considered. The obtained values of such indicators as optical density, tone reproduction, print stability, resolution have confirmed that in the areas of the wave height of the corrugation there is a higher printing pressure, which leads to better ink transfer.

Keywords: corrugated cardboard, flexography, printing, simulation.

Problem statement. Researchers claim that packaging will exist regardless of the market situation, international conflicts and will develop in certain countries depending on the conditions of society, use of goods and consumer needs [1]. In the future, there may come a time when a person will be replaced by robots, but packaging as an artefact of the market will undoubtedly function over time and perform its tasks. Production of ecological packaging ensures business success. This was confirmed by $96 \%$ of respondents - manufacturers of corrugated packaging, when conducting a survey by the English company Smithers Pira commissioned by Pro Carton. More than $50 \%$ of packaging manufacturers in different countries of the world prefer ecological, durable and at the same time light, easy to finish with printing technologies, capable of recycling corrugated cardboard [2]. The combination of technological and consumer properties has allowed corrugated cardboard to take a priority position in the global packaging market. The experience of foreign countries shows that the use of corrugated packaging with improved performance is the most effective, as it significantly expands its scope, improves quality and ensures economical use of resources for packaging.

The advantages of corrugated packaging include:

- small own weight, in comparison with a container from plastic and wood, that allows to facilitate process of loading-unloading of the goods and to save fuel at logistical operations; 
- low cost, especially compared with containers made of hard plastic or wood;

- compactness - corrugated cardboard packaging is delivered to enterprises, where it will be filled with products, in a folded flat form, and collected in bulk boxes immediately before filling;

- the ability to reproduce printing technologies, including the use of multicolor printing. It is possible to implement offset, screen, flexographic printing, etc.;

- universality and versatility - the ability to use for the transportation of goods with various properties, such as food, household appliances, clothing, furniture, etc.;

- natural reproducibility of raw materials for corrugated packaging in the environment, much less impact on the environment, compared to plastic containers. It is also possible to reuse raw materials, for example for the production of waste cardboard.

The disadvantages of transport corrugated packaging include its high gas and moisture permeability. But this problem can be partially solved by using cardboard surface lamination and varnishing. Also, one of the disadvantages of corrugated packaging is the lack of strength and stiffness, which limits the height of the stacking of transport pallets. In addition, the stiffness is significantly reduced during long-term storage, especially in environments with excessive humidity.

Analysis of recent research and publications. As it is known, for the manufacture of corrugated cardboard modern manufacturers produce a wide range of liners and flutings. The liners - flat layers - can be waste paper, test liner or kraft liner and will have a brown or white surface accordingly, which can be coated or semi-coated depending on the intended application. Fluting - the basis for corrugation - is usually waste paper. For liners such cardboard is used: multilayer box cardboard (chrome-ersatz, FBB, GC or UC), pure cellulose coated cardboard from bleached cellulose (SBB, SBS or GZ), pure cellulose coated cardboard from unbleached cellulose (SUB or SUS), waste coated cardboard (WLC, GD, GT or UD), not coated cardboard. The thickness of corrugated cardboard will depend on the height of the fluting and can vary from $0.5 \mathrm{~mm}$ for the thinnest cardboard to $15 \mathrm{~mm}$ (and sometimes more) for the thickest. Depending on the height of the corrugated layer, the following profiles of corrugated cardboard are distinguished:

- large (profile A) - has a wave height of 4.6-5.2 mm;

- small (profile B) - has a wave height of 2.5-3.2 mm;

- medium (profile C) - has a wave height of 3.6-4.3 mm;

- micro corrugated cardboard (profile E) - has a wave height of 1.1-1.7 mm.

Depending on the number of layers, there are the following types of corrugated cardboard: two-layer, three-layer, five-layer, seven-layer [3].

Despite the fact that the transport packaging made of corrugated cardboard is still far from perfect, the list of its advantages clearly exceeds the number of disadvantages. Widespread use of corrugated packaging, its low cost and possibility of utilization without harming the environment allow manufacturers of this type of packaging to constantly create new samples of packaging and successfully implement them in various areas of consumer consumption. 
Therefore, the attention of researchers is attracted by the decoration of corrugated cardboard packaging using the latest printing techniques. Among the many basic printing technologies for reproducing textual information and illustrative images on corrugated cardboard packaging, flexographic and digital printing deserve special attention [4]. It is known that the quality of printing is affected by many factors that depend on the chosen technology of image application, the printed surface, its properties, printing plate and so on. In [5], a research of the transfer of ink from the printing plate to the printed material is carried out, the results of which showed a significant dependence of ink transfer on the surface energy of the contact surfaces. The theoretical assumption about the possibility of obtaining the value of the ink transfer coefficient of about 0.5 in the contact zone "printing plate - printed material" is confirmed, provided that the wetting edges of both surfaces are the same. Normalization of ink transfer by systems with anilox rollers is studied in [6], in particular, the nature of the ink movement from the cells of anilox roller of different geometry, its stabilization in the reproduction of textual and illustrative information of different nature [7]. The influence of the structure of the anilox roller on fine-line printing in the process of flexographic printing was studied in [8]. The phenomena of deformation of the flexographic photopolymer printing form were studied in [9]. Absence for today of scientifically sound recommendations for regulating the parameters of the ink transfer process by anilox systems leads to instability of the printing process, color reproduction, defects of imprints

The aim of the research. The aim of the work was to study the stress-strain state of corrugated cardboard during flexographic printing and its influence on the prediction of imprints quality.

Presentation of the main research material. The objects of research were imprints of flexographic printing on five-layer corrugated cardboard BE (liner TLW), made on a sheet flexographic machine Gopfert Ovation 13/21. Printing was performed with the following parameters - with an average sheet length of $1 \mathrm{~m}$, the printing speed was $1.3 \mathrm{~m} / \mathrm{s}$ with water-soluble inks EURO-BOARD (manufacturer DONESK Euroflex S.A., Luxsemburg):

- Cyan WKA3485 (kinematic stickiness 25-35 s) (according to DIN53211/4);

- Magenta WKA2499 (kinematic stickiness 20-30 s;

- Yellow WKA1253 (kinematic stickiness 20-30 s;

- Black WKA8294 (kinematic stickiness 20-30 s;

It was used a GGT ink cylinder with a cell capacity of $6.6 \mathrm{~cm} 3 / \mathrm{m} 2$, which theoretically allows the transfer of ink on the substrate $2.5 \mathrm{~g} / \mathrm{m} 2$ (manufacturer Apex Europe B.V.).

The method of assessing the quality of imprints involved the determination of such parameters as tone transfer, optical density (using a spectrodensitometer X-Rite 528 for CMYK colors); distinguishing the range of colors. The resistance to abrasion of the printed image was determined on the device type IMR. The stability of printing on a sheet of corrugated cardboard was measured by the color parameters $L^{*}, a *, b *$ of the three control fields, determining the average values for each of the three fields and calculating $\Delta \mathrm{E} * \mathrm{ab}$. This took into account the requirements of ISO 12647-6, according 
to which the standard deviation $\mathrm{L} *, \mathrm{a} *, \mathrm{~b} *$ should not exceed 0.5 , and $\Delta \mathrm{E} *$ ab between the mean and each field should not exceed $\Delta \mathrm{E} * \mathrm{ab}=2[10]$.

Investigations of the processes influencing the stress-strain state of the corrugated cardboard surface were performed using the methods of the theory of elasticity $[11,12]$. In particular, the basic equations of the theory are taken into account for the calculation of stresses and strains of corrugated cardboard components in flexographic printing, taking into account geometric and physical nonlinearity in elastic bodies of incompressible material under the action of force fields. The problem of optimization of the stress-strain state on the basis of the nonlinear spatial theory of thermo elasticity is formulated. The use of a mathematical apparatus for the study of displacements is substantiated. Let the body deform elastically. Then the point of the body with coordinates will receive displacement, which can be transmitted by three projections of the vector of complete displacement on the directions of the tangents to the coordinate lines:

$$
u_{1}=u_{1}(\alpha, \beta, \gamma), u_{2}=u_{2}(\alpha, \beta, \gamma), u_{3}=u_{3}(\alpha, \beta, \gamma) \text {. }
$$

Relative elongations in the directions $\alpha, \beta, \gamma$ are calculated by formulas:

Shear angles between fibers:

$$
E_{1}=\sqrt{1+2 \varepsilon_{11}}-1, E_{2}=\sqrt{1+2 \varepsilon_{22}}-1, E_{3}=\sqrt{1+2 \varepsilon_{23}}-1 \text {. }
$$

$$
\sin f_{12}=\frac{\varepsilon_{12}}{\left(1+E_{1}\right)\left(1+E_{2}\right)}, \sin f_{23}=\frac{\varepsilon_{23}}{\left(1+E_{2}\right)\left(1+E_{3}\right)}, \sin f_{13}=\frac{\varepsilon_{13}}{\left(1+E_{1}\right)\left(1+E_{3}\right)} \text {. }
$$

The unit vectors $\overrightarrow{K_{1}^{*}}, \overrightarrow{K_{2}^{*}}, \overrightarrow{K_{3}^{*}}$ tangent to the lines $\alpha, \beta, \gamma$ in the body after deformation are found by the formulas:

$$
\begin{aligned}
& \overrightarrow{K_{1}^{*}}=\frac{1}{1+E_{1}}\left[\left(1+\ell_{11}\right) \overrightarrow{K_{1}}+\left(\frac{1}{2} \ell_{12}+\omega_{3}\right) \overrightarrow{K_{2}}+\left(\frac{1}{2} \ell_{13}-\omega_{2}\right) \overrightarrow{K_{3}}\right], \\
& \overrightarrow{K_{2}^{*}}=\frac{1}{1+E_{2}}\left[\left(\frac{1}{2} \ell_{12}-\omega_{3}\right) \overrightarrow{K_{1}}+\left(1+\ell_{22}\right) \overrightarrow{K_{2}}+\left(\frac{1}{2} \ell_{23}+\omega_{1}\right) \overrightarrow{K_{3}}\right], \\
& \overrightarrow{K_{3}^{*}}=\frac{1}{1+E_{3}}\left[\left(\frac{1}{2} \ell_{13}+\omega_{2}\right) \overrightarrow{K_{1}}+\left(\frac{1}{2} \ell_{23}-\omega_{1}\right) \overrightarrow{K_{2}}+\left(1+\ell_{33}\right) \overrightarrow{K_{3}}\right] .
\end{aligned}
$$

To determine the stress-strain state and temperature, the geometric configuration of the body, the properties of the thermoelastic material by the dependence of free energy on deformation and temperature, the coefficient of thermal conductivity, mass forces and boundary conditions should be specified. The main functions of the nonlinearity of thermo elasticity are the components of the vector and the temperature $\mathrm{T}$. We denote the function by the vector

$$
\varphi=\left\{u_{1}, u_{2}, u_{3}, T\right\}
$$

Similarly, to (5), we denote by the value of $\mathrm{F}$ the vector of functions that characterize the force and temperature actions, the geometric configuration of the body, mechanical and thermophysical characteristics of the material:

$$
F=\left(F_{1}, F_{2}, \ldots, F_{n}\right) \text {. }
$$

Direct boundary problem of thermo elasticity can now be written as

$$
\begin{aligned}
& L(f, F)=0 . \\
& C(f, F)=0,
\end{aligned}
$$


where the operator L- corresponds to the four equations for the components of displacements and temperature, and the operator B- boundary force and temperature conditions.

When setting the optimization problem, we assume that the area of change of the function $\mathrm{F}$ is limited:

$$
F^{-} \leq F \leq F^{+},
$$

where $F^{-}, F^{+}$- given functions or parameters that characterize the range of possible changes in force and temperature actions, the geometric configuration of the body, mechanical and thermophysical characteristics of the material.

Area of change of functions $f$ can also be limited, namely the direct boundary problem of thermo elasticity can now be written in the form

$$
f^{-} \leq f \leq f^{+},
$$

where $f^{-}, f^{+}$- given functions that characterize the area of temperature change and the component of movement in the body.

Limits can be set on stress, strain, temperature gradient inside the body and on the surface, as well as other parameters. Therefore, the limitation of the optimization problem in the general case are written as

$$
B^{-} \leq A(f, F) \leq B^{+},
$$

where $A$ - given operator; $B^{-}, B^{+}$- known functions.

Optimization of the stress-strain state is required to ensure needed optimization criterion

$$
K=Q(Y)
$$

where $\mathrm{Q}$ - given operator; $\mathrm{Y}$ - control function.

$$
Y=Z(F, f) \text {. }
$$

The formulated problem of optimization of the stress-strain state on the basis of the nonlinear spatial theory of elasticity makes it possible to consider the set of partial problems when specifying the control function (13) and the optimization criterion (12).

The optimization criterion can be written as

or

$$
\min \left(\max _{\alpha, \beta, \gamma}\left(\sigma_{u}\right)\right) \text {, }
$$

$$
\min \left(\max _{\alpha, \beta, \gamma}\left(u_{H}\right)\right) \text {, }
$$

where $\sigma_{u}$ - stress intensity; $u_{H}$ - moving the points of the deforming body in a given direction.

The optimization of the stress-strain state of corrugated cardboard is based on the modular principle. The differential method of increasing accuracy, suitable for determining the optimal stress-strain state, is adopted in the work. Sampling of the geometric configuration of the body is carried out according to the selected coordinate system $\alpha, \beta, \gamma$. In the field of changing variables $\alpha, \beta, \gamma$ we build a spatial grid of lines

$$
\begin{gathered}
\alpha=\text { const }, \beta=\text { const }, \gamma=\text { const }, \\
\alpha_{i}=(i-1) h_{\alpha}, \beta_{i}=(j-1) h_{\beta}, \gamma_{K}=(K-1) h_{\gamma},
\end{gathered}
$$

where $h_{\alpha}, h_{\beta}, h_{\gamma}$ - grid steps in directions $\alpha, \beta, \gamma:\left(i=1,2, \ldots, i_{1} ; j=1,2, \ldots, j_{1} ; K=1\right.$, $\left.2, \ldots, K_{1}\right)$. The points of intersection of lines form a set of nodes $\Omega_{N}\left\{\alpha_{i}, \beta_{j}, \gamma_{K}\right\}$ that are used to discretize the defining and basic functions, the boundary optimization problem. 
Tabular functions of displacements, deformations and stresses are introduced into the grid nodes. Defining functions $F$ similarly pass to discretely set

$$
F_{i j K}=F\left(\alpha_{i}, \beta_{j}, \gamma_{K}\right) \text {. }
$$

The initial equations that determine the stress-strain state of corrugated cardboard during flexographic printing, as shells under the action of force fields, contain geometric and physical relations, equilibrium equations, boundary conditions.

The study of stresses and strains in elastic bodies made of incompressible material - corrugated cardboard was carried out taking into account the geometric nonlinearity in the spatial ratios of elasticity when calculating thick shells, plates and structural elements. In the numerical solution of the direct problem of elasticity in incompressible bodies, in addition to the equations of equilibrium in displacements, the equation of incompressibility must be satisfied, namely, in addition to the components of displacements, the hydrostatic pressure must be determined $h$. The basic nonlinear equations of elasticity in the Cartesian coordinate system $\left(x_{1}, x_{2}, x_{3}\right)$ have the following form:

$$
\begin{gathered}
L_{1}\left(u_{i}, h\right) \equiv \sigma_{11}^{*} \frac{\partial^{2} u_{1}}{\partial x_{1}^{2}}+\sigma_{22}^{*} \frac{\partial^{2} u_{1}}{\partial x_{2}^{2}}+\sigma_{33}^{*} \frac{\partial^{2} u_{1}}{\partial x_{3}^{2}}+2 \sigma_{12}^{*} \frac{\partial^{2} u_{1}}{\partial x_{1} \partial x_{2}}+ \\
+2 \sigma_{13}^{*} \frac{\partial^{2} u_{1}}{\partial x_{1} \partial x_{3}}+2 \sigma_{23}^{*} \frac{\partial^{2} u_{1}}{\partial x_{2} \partial x_{3}}+\left(\frac{\partial \sigma_{12}^{*}}{\partial x_{1}}+\frac{\partial \sigma_{23}^{*}}{\partial x_{2}}+\frac{\partial \sigma_{33}^{*}}{\partial x_{3}}\right) \frac{\partial u_{1}}{\partial x_{3}}+ \\
+\left(\frac{\partial \sigma_{11}^{*}}{\partial x_{1}}+\frac{\partial \sigma_{12}^{*}}{\partial x_{2}}+\frac{\partial \sigma_{13}^{*}}{\partial x_{3}}\right)\left(1+\frac{\partial u_{1}}{\partial x_{1}}\right)+\left(\frac{\partial \sigma_{12}^{*}}{\partial x_{1}}+\frac{\partial \sigma_{23}^{*}}{\partial x_{2}}+\frac{\partial \sigma_{33}^{*}}{\partial x_{3}}\right) \frac{\partial u_{1}}{\partial x_{2}}=0 \\
L_{2}\left(u_{i}, h\right)=0, \quad L_{3}\left(u_{i}, h\right)=0, \quad L_{4}\left(u_{i}\right) \equiv \operatorname{det}\left\|\delta_{r s}-\frac{\partial u_{r}}{\partial x_{s}}\right\|-1=0 .
\end{gathered}
$$

Equation (19) is obtained from (18) by cyclic permutation $\left(u_{1}, u_{2}, u_{3}\right)$ and $\left(x_{1}\right.$, $\left.x_{2}, x_{3}\right)$. In the Cartesian coordinate system, it is convenient to calculate elastic bodies with a geometry that agrees with the parallelepiped partition by the difference method. Deformations in in the structure at compression by force $q$ are important.

Suppose that in a rectangular coordinate system we have an elastic plate of dimensions $2 a x 2 b x c$ with a trapezoidal groove in height (Fig. 1). The coordinate system $\left(x_{1}, x_{2}, x_{3}\right)$ is chosen so that $-a \leq x_{1} \leq a,-b \leq x_{2} \leq b, 0 \leq x_{3} \leq c+h_{n}$.

The results of the maximum deformations $\varepsilon_{M}$ during compression of corrugated cardboard depending on the applied force for different values of the angle are shown in Fig. 1. Studies have shown that with increasing force $q$, the value of the maximum deformation increases by a nonlinear law. As the corrugation profile increases (angle $\alpha$ from $65^{\circ}$ to $85^{\circ}$ ), the maximum deformations in the material also increase.

Thus, taking into account the geometric nonlinearity in the spatial ratios of elasticity in the calculation of thick shells, plates and elements of structures, the study of stresses and strains of corrugated cardboard during flexographic printing was conducted. The evaluation of imprints quality indicators was carried out. Table 1 shows the values of the imprint's optical density printed by the corrugations B and E. As can be seen, a slightly higher optical density is recorded when printing from the corrugation $\mathrm{E}$ and is 0.89 than 
when printing from the corrugation $\mathrm{B}$, which is more susceptible to deformation during printing (with the same liners) and is 0.86 .

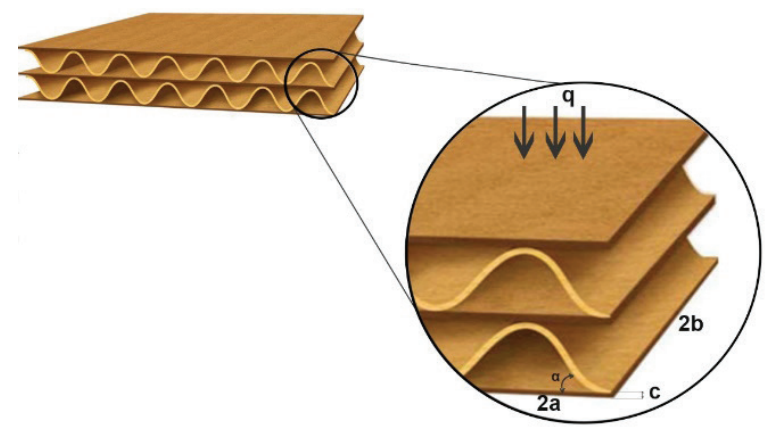

Fig. 1. Model for calculating the stress state of corrugated cardboard

Table 1

The value of imprints optical densities

\begin{tabular}{|c|c|c|c|c|c|}
\hline Corrugated cardboard & C & M & Y & K & average CMYK \\
\hline TLW-E & 0.9 & 0.91 & 0.79 & 0.98 & 0.89 \\
\hline TLW-B & 0.83 & 0.88 & 0.7 & 1.02 & 0.86 \\
\hline
\end{tabular}

The diagram of the accuracy of color reproduction and the definition of $\Delta \mathrm{E}$ allowed to build the surface of the circle of color coverage, the area of which is much larger on the imprints obtained from the corrugation E (Fig.2). The best values are obtained on the imprint printed from the corrugation $\mathrm{E}$, where the color coverage is $15 \%$ higher than the value on the imprint obtained on the same liner from the corrugation $\mathrm{B}$.

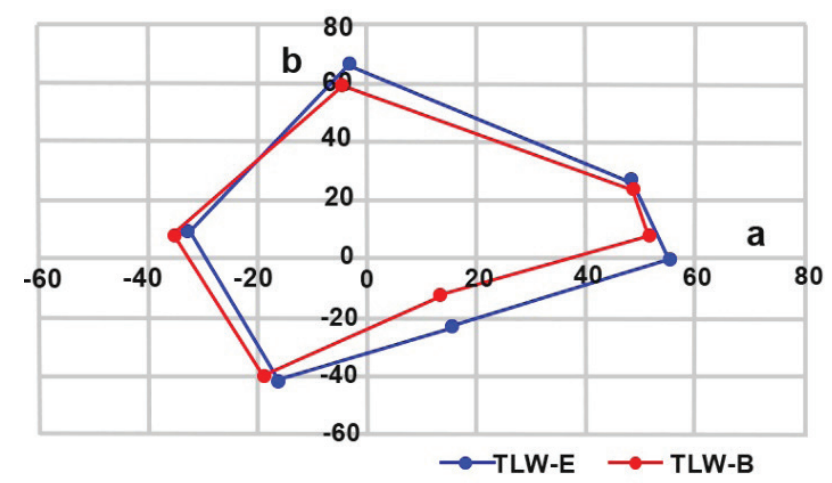

Fig. 2. Diagram of the color coverage of the imprint's images 
The resolution of imprints also depends on which side of the corrugation was printed (Fig. 3).

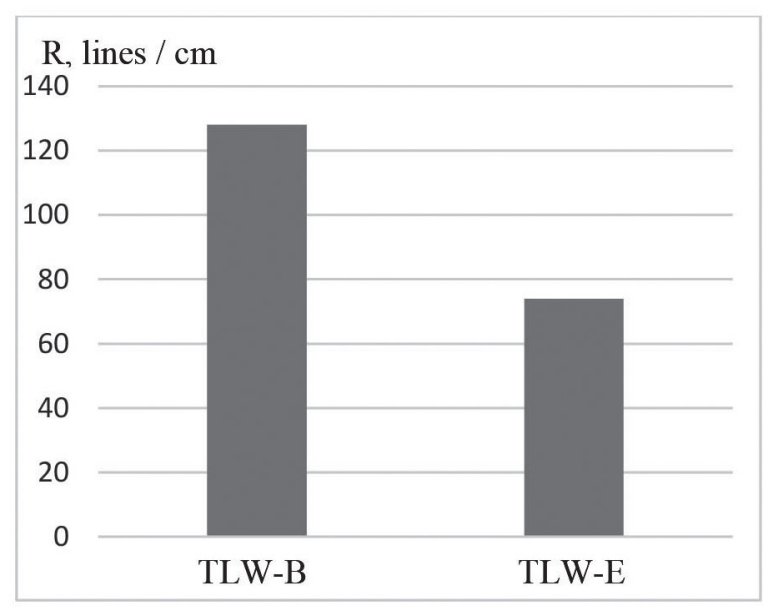

Fig. 3. Diagram of imprints resolution

As it can be seen, the imprints printed on the side of the corrugation E have a resolution of 128 lines / cm, while the imprints obtained on the side of the corrugations B - 74 lines $/ \mathrm{cm}$.

When determining the stability of printing (Fig. 4), it was found that greater stability of printing have imprints on TLW-E (flexographic printing from the corrugation E), where $\Delta \mathrm{Eab}$ max averages 3.70 (4.12 - for light tones, 3.48 - for medium and 3.26 - for dark areas of the image). For imprints printed on the side of the corrugations $B$, the average values of $\Delta \mathrm{E}$ max are 2.74. (1.49 for light tones, 2.69 for medium and 2.58 for dark areas of the image).

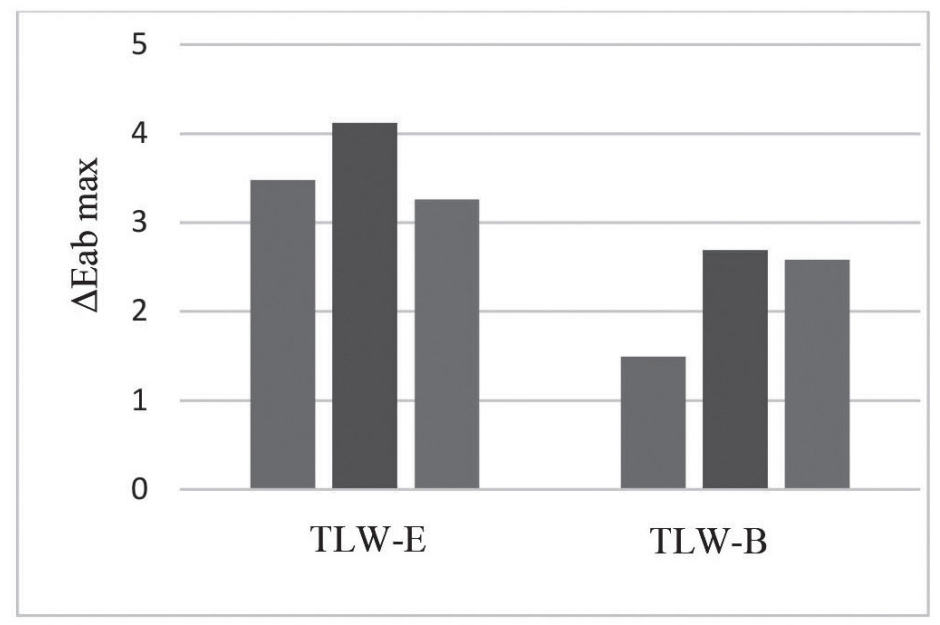

Fig. 4. Diagram of printing stability 
Therefore, changes in the pressure in the area of printing contact, associated with the internal structure of the stress-strain state of corrugated cardboard, are important, because they cause changes in the optical density of full fields $(100 \%)$, the degree of coverage of raster fields. In the wave height zones of the corrugation there is a greater printing pressure, which leads to better ink transfer and, consequently, an increase in optical density. In places of halftone fields, greater pressure causes an increase in the growth of raster tonal value. This can obviously explain the more uniform pressure distribution between the printing plate and the liner due to the lower height of the corrugation, the reduction of deformation when printing from the corrugation $\mathrm{E}$ on corrugated cardboard.

Conclusions. The formulated problem of optimization of the stress-strain state of corrugated cardboard on the basis of nonlinear spatial theory of elasticity allows to consider the set of partial problems when specifying the control function, the criterion for optimizing the stress intensity; moving the deformed points of the body in a given direction.

Thus, it is confirmed that the elastic-deformation state of corrugated cardboard in the process of flexographic printing on it, has an impact on the qualitative indicators of the received imprints. Printing of corrugated cardboard from the side of corrugation E has better quality indicators (optical density, color reproduction, print stability) compared to imprints printed from the side of corrugation B. This is obviously due to the greater deformation of the inner layers of corrugation $\mathrm{B}$, which has a greater height (2.5$3.2 \mathrm{~mm}$ ), compared with corrugation $\mathrm{E}(1.1-1.7 \mathrm{~mm})$. The defect is known as a "washing board" - the appearance of dark and light streaks in the image, found on the imprints on the side of the corrugation $\mathrm{B}$, which is not visible on the imprints on the side of the corrugation E, which confirms the effect of stress deformation of corrugated cardboard on image quality. A more uniform pressure distribution and stress redistribution during liner printing from the lower height of the corrugation $\mathrm{E}$ have been confirmed, which indicates the formation of better imprints in post-print.

\section{СПИСОК ВИКОРИСТАНИХ ДЖЕРЕЛ}

1. Kubera H. Problems and conditions for the development of future packaging. Packaging industry in Poland. State. Perspectives. Offer : monography. Warsaw : Polish Chamber of Packaging, 2012. C. 25-34.

2. Eco-friendly packaging fosters sales growth. Paper review. 2017. 518 p.

3. Corrugated board structure: features, marking, types. URL: http://www.mpzp.ru/art/63781917. html.

4. Ischimenler E. «Digital» on corrugated cardboard. Packaging. 2017. No 6. Pp. 38-39.

5. Determination of factors influencing the quality of test imprints of flexographic printing / Havenko S., Ohirko M., Ryvak P., Kotmalyova O. East European Journal of Advanced Technologies. 2020. ISSUE 2, 5 (104). Pp. 53-63.

6. Blagodir O., Velychko O. Study of anilox cell geometry impact on the ink volume transferred to the printing plate. Paper review. 2016. № 1 (7). Pp. 49-53.

7. Stępien K. Method and device for the control and the management of the printing parameters of a flexographic printing machine. Packaging. 2017. № 4. Pp. 79-96. 
8. The Effects of Annilox Roller on Fine Line Printing in Flexographic Printing Process / Yusof M. S., Ahmad Zaidi A. M., Claypole T. C., Gethin D. T. Proceedings 2nd International Conference on Print and Media Technology. Chemnitz, 2007. Pp. 211-213.

9. Application of Finite Elements on Non-Linear Deformation of Flexographic Photopolymer Printing Plate / Yusof M. S., Claypole T. C., Gethin D. T., Ahmad Zaidi A. M. Proceedings of the World Congress on Engineering 2008. Vol II WCE 2008, July 2-4. 2008.

10. ISO 12647-6:2012. Graphic technology - Process control for the production of half-tone colour separations, proofs and production prints - Part 6:Flexographic printing.

11. Alexandrov A. V., Potapov V. D. Fundamentals of the theory of elasticity and plasticity. Higher school, 1990. 400 p.

12. Bozhidarnik V. V., Sulim G. T. Elements of the theory of plasticity and strength. Lviv : Svit, 1999. $417 \mathrm{p}$.

\section{REFERENCES}

1. Kubera, H. (2012). Problems and conditions for the development of future packaging. Packaging industry in Poland. State. Perspectives. Offer. Warsaw: Polish Chamber of Packaging (in Polish).

2. Eco-friendly packaging fosters sales growth. Paper review. (2017) (in Polish).

3. Corrugated board structure: features, marking, types. Retrieved from http://www.mpzp.ru/ art/63781917.html (in Russian).

4. Ischimenler, E. (2017). «Digital» on corrugated cardboard. Packaging, 6, 38-39 (in Ukrainian).

5. Havenko, S., Ohirko, M., Ryvak, P., \& Kotmalyova, O. (2020). Determination of factors influencing the quality of test imprints of flexographic printing. East European Journal of Advanced Technologies, 2, 5 (104), 53-63 (in Ukrainian).

6. Blagodir, O., \& Velychko, O. (2016). Study of anilox cell geometry impact on the ink volume transferred to the printing plate. Paper review, 1 (7), 49-53 (in Polish).

7. Stępień, K. (2017). Method and device for the control and the management of the printing parameters of a flexographic printing machine. Packaging, 4, 79-96 (in Polish).

8. Yusof, M. S., Ahmad Zaidi, A. M., Claypole, T. C., \& Gethin, D. T. (2007). The Effects of Annilox Roller on Fine Line Printing in Flexographic Printing Process. Proceedings 2nd International Conference on Print and Media Technology. Chemnitz (in English).

9. Yusof, M. S., Claypole, T. C., Gethin, D. T., \& Ahmad Zaidi, A. M. (2008). Application of Finite Elements on Non-Linear Deformation of Flexographic Photopolymer Printing Plate. Proceedings of the World Congress on Engineering 2008, II WCE 2008, July 2-4 (in English).

10. ISO 12647-6:2012. Graphic technology - Process control for the production of half-tone colour separations, proofs and production prints - Part 6:Flexographic printing (in English).

11. Alexandrov, A. V., \& Potapov, V. D. (1990). Fundamentals of the theory of elasticity and plasticity. Higher school (in Russian).

12. Bozhidarnik, V. V., \& Sulim, G. T. (1999). Elements of the theory of plasticity and strength. Lviv : Svit (in Ukrainian).

doi: 10.32403/1998-6912-2021-1-62-122-132 


\title{
МОДЕЛЮВАННЯ НАПРУЖЕНО-ДЕФОРМОВАНОГО СТАНУ ГОФРОКАРТОНУ ПРИ ФЛЕКСОГРАФІЧНОМУ ДРУЦІ ТА ЙОГО ВПЛИВ НА ЯКІСТЬ ВІДБИТКІВ
}

\author{
М. О. Огірко, С. Ф. Гавенко, М. Т. Лабецька, С. Чубак \\ Українська академія друкарства, \\ вул. Під Голоском, 19, Львів, 79020, Україна \\ havenko1559@gmail.com
}

Здійснено імітаційне моделювання напружено-деформованого стану пятишарового гофрокартону під час друкування на аркушевій флексографічній машині. Дослідження базуються на основних рівняннях теорії розрахунку напружень $i$ деформацій, щуо враховують геометричну та фізичну нелінійність у пружних тілах з не стисливого матеріалу, який перебуває під дією силових полів. Передбачається, щзо аркуш гофрокартону не повинен підлягати заминанню при друкуванні, так як ие приводить до спотворення елементів зображення. Сформульована задача оптимізації напружено-деформованого стану гофрокартону на основі нелінійної просторової теорії пружності дає змогу розглянути множину часткових задач при конкретизації функиії керування, критерій оптимізації інтенсивності напружень; переміщення точок тіла, щзо деформуються, в заданому напрямі. Для визначення оптимального напружено-деформованого стану гофрокартону прийнято різницевий метод підвищення точності. Розглянуто максимальні деформації при стисканні конструкиї аркуша гофрокарону, задрукованого з боку гофри $B i$ E, залежно від прикладеної сили для різних значень кута при основі хвилі гофри. Досліджено якість відбитків, отриманих на аркушевихмашинах флексографічного друку. Отримані значення таких показників, як оптична щільність, тоновідтворення, стабільність друку, роздільна здатність, підтвердили, щзо у зонах висоти хвилі гофри спостерігається більший тиск друку, щзо призводить до кращзого перенесення фарби. Одночасно, відбитки, отримані при задруковуванні гофрокартону з боку гофри E, мають кращі значення, ніж з боку гофри $B$, що очевидно пояснюється рівномірнішим розподілом напружень $і$ деформацій з боку меншої висоти гофри Е. Виявлено на відбитках з боку гофри В дефект відомий як «пральна дошка» - поява темних і світлих смуг на зображенні, чого не видно на відбитку з боку гофри Е, чим підтверджується вплив напруженого деформованого стану гофрокартону на якість зображень. Підтверджено рівномірніший розподіл тиску, перерозподіл напружень при задруковуванні лайнеру з боку меншої висоти гофри Е , щзо свідчить про утворення якісніших відбитків при post-print.

Ключові слова: гофрокартон, флексографія, друкування, моделювання. 